\title{
Quantifying future changes in glacier melt and river runoff in the headwaters of the Urumqi River, China
}

\author{
Yiqing Zhang ${ }^{1,2} \cdot$ Yi Luo ${ }^{1,2} \cdot$ Lin Sun ${ }^{1}$
}

Received: 15 September 2015/Accepted: 15 March 2016/Published online: 25 April 2016

(C) Springer-Verlag Berlin Heidelberg 2016

\begin{abstract}
Climate change is likely to have significant effects on the water cycle in glacierized basins. Here, the glacier-enhanced Soil and Water Assessment Tool (SWAT) was employed to simulate glacio-hydrological processes and to estimate the potential hydrological changes driven by downscaled future climate projections of five Global Circulation Models (GCMs) under three Representative Concentration Pathways (RCPs) in the headwaters of the Urumqi River, Tianshan Mountains, China. The evaluation indices indicated that the model performed well at simulating streamflow during the calibration and validation. The GCM-predicted mean temperature and precipitation both increase. The periods of 1966-1995, 2016-2045 and 2066-2095 were used as the baseline, the near future, and the far future periods, respectively. The results showed different runoff characteristics under various scenarios in the Urumqi Glacier No. 1 (UG1) sub-basin and Urumqi River Basin (URB) due to distinct melt water contributions. In the UG1 sub-basin, the ice melt and glacier melt are expected to reach peak water in the near future and sharply decline in the far future, and the subbasin runoff would gradually decrease under all RCPs. In
\end{abstract}

Electronic supplementary material The online version of this article (doi:10.1007/s12665-016-5563-z) contains supplementary material, which is available to authorized users.

Yi Luo

luoyi@igsnrr.ac.cn

1 Key Laboratory of Ecosystem Network Observation and Modeling, Institute of Geographic Sciences and Natural Resources Research, Chinese Academy of Sciences, No 11A, Datun Road, Chaoyang District, Beijing 100101, China

2 University of Chinese Academy of Sciences, Beijing 100049, China the URB, the ice melt and glacier melt rapidly decrease but the river runoff remains stable under RCP 2.6 and RCP 4.5, with a slight decrease under RCP 8.5 . The grouped glacier area with small size class shows a rapid retreat rate. It was also found that melt water from three grouped glaciers exhibit different responses to future scenarios.

Keywords Climate change - Glacier melt - Runoff . GCMs

\section{Introduction}

Glacio-hydrological processes play an important role in regulating river runoff in glacierized basins. Climate change is likely to cause varied hydrological impacts due to the spatial and temporal variation of temperature and precipitation (Abdo et al. 2009; Singh et al. 2014). Global warming has accelerated glacier retreat in the last decades (Li et al. 2006; Bolch 2007). In the short term, glacier retreat may result in increased melt water and downstream benefits, as the loss of glacier mass supplements river runoff (Sorg et al. 2014). However, this effect is unsustainable as the amount of melt water decreases with continuous glacier volume loss and weakens the regulation of summer runoff, thus creating future problems for water resource allocation during the dry seasons in densely populated arid lowlands. Therefore, the potential change in water resources due to retreating glaciers should be quantitatively assessed.

Many studies have focused on future glacier retreat-related hydrological changes at the basin scale (Baraer et al. 2012). One of the most pressing issues is the ongoing changes in glacier melt and river runoff. The river runoff largely contributed by melt water will be significantly 
affected by climate change; however, it remains uncertain exactly when glacierized rivers will cross peak water. Some studies have suggested that the water supply will peak after several decades of continually increases as a result of the net glacier volume loss, which will then be followed by a sudden decrease (Jansson et al. 2003; Pouyaud et al. 2005; Baraer et al. 2012). Nevertheless, it has been suggested that glacier retreat could lead to a decrease in melt water because less of the glacier mass is converted to runoff over time. This perspective can also be explained theoretically if the tipping point of melt water has already passed. Moreover, the year-to-year variability of surface runoff tends to increase when glacier melt reaches its peak water, resulting in the loss of some buffering capacity (Braun and Hagg 2009). These issues should not be present only in large glacierized basins but also in basins covered by small glaciers that will rapidly disappear due to global warming.

More attention should be paid to the potential hydrological changes of small glacierized basins that have large glacier melt contribution. Small glaciers are expected to show a rapid response to climate change, and recent studies have shown they have larger relative area loss than large basins (Kriegel et al. 2013; Wang et al. 2015). These small glaciers also exhibit a larger variability in both the magnitude and the sign of area changes (Unger-Shayesteh et al. 2013) and can contribute favorably to river runoff (Jansson et al. 2003). Little glacierized river basins with significant glacier melt contribution are particularly vulnerable to global warming, as they are expected to shift from glacialnival to nival-pluvial runoff and lose regulation capacity in a short time.

Unger-Shayesteh et al. (2013) highlighted that our knowledge is lacking with regard to the magnitude and spatio-temporal patterns of changes in glacio-hydrological processes in the Tianshan Mountains. Detailed glacial runoff observations are imperative for the accurate evaluation of glacier recession and changes in water resources (Gao et al. 2013). However, very few glaciers in this region are monitored long term due to the lack of suitable geographical sites to measure the contribution of glaciers to the water cycle (Suarez et al. 2008). Urumqi Glacier No. 1 (UG1) $\left(43^{\circ} 06^{\prime} \mathrm{N}, 86^{\circ} 49^{\prime} \mathrm{E}\right)$ is a representative long-term, small glacier that has been monitored since 1959 and is ranked the second largest glacier in the headwaters of Urumqi River Basin (URB), Tianshan Mountains, China (Han et al. 2011; Chen et al. 2012; Feng et al. 2012). The streamflow at the outlet of URB has also been long-term observed. Although the Urumqi River is mainly fed by rainfall, the glacierized headwaters may be a valid regional representative to investigate how climate change affects glacio-hydrological processes. The runoff from the UG1 sub-basin has significantly increased from 1959 to 2006 due to negative glacier mass balance and increasing precipitation ( $\mathrm{Li}$ et al. 2010). But, glacier melt could not be separated from the total observed runoff. The increased river runoff could be a result of increased glacier melt but also could be due to increased precipitation. The accurate estimation of glacier melt contribution to runoff is critical to the understanding of runoff components. Furthermore, the potential changes in glacier melt and runoff in the headwaters of the Urumqi River under future climate conditions have been explored very little. Glacio-hydrological models are the most effective tool to investigate the characteristics of hydrological processes and to rigorously establish links between glacier retreat and river runoff (Unger-Shayesteh et al. 2013). Coupled general circulation models (GCMs) are valuable tools because they indicate how flow distributions may shift under a wide range of future climate conditions (Dickerson-Lange and Mitchell 2014).

The objectives of this study were to explore the potential changes in glacier melt and river runoff in the headwaters of the Urumqi River using a physically based, distributed hydrological model with downscaled GCMs under different future climate scenarios.

\section{Methods and data}

\section{Study site}

The Urumqi River Basin (URB) is located in the northern flank of the Eastern Tianshan Mountains, approximately $175 \mathrm{~km}$ from Urumqi, the capital of Xinjiang Uygur Autonomous Region, China (Fig. 1). The river originates from the northern slope of Tiager Peak and is surrounded by the Taklimakan Desert, the Gurbantunggut Desert and the Gobi Desert. The basin is influenced by westerly circulation and has a temperate, continental, and arid climate. The basin climate is classified as sub-humid and precipitation mainly occurs during summer months (June to August) with a mean of $480 \mathrm{~mm}$ (Zhang et al. 2005; Zhao et al. 2008). The drainage area of the Urumqi River is located above the Yingxiongqiao Hydrological Station (YHS) $\left(43^{\circ} 22^{\prime} \mathrm{N}, 87^{\circ} 12^{\prime} \mathrm{E}\right)$ and is $923.4 \mathrm{~km}^{2}$. The elevation of the YHS ranges from 1878 to $4445 \mathrm{~m}$ (mean of $3090 \mathrm{~m}$ ). The basin environment includes a forest zone below $2900 \mathrm{~m}$, alpine meadows, bare rock, glacial deposits and permafrost above $2900 \mathrm{~m}$ ( $\mathrm{Li}$ et al. 2010).

Based on the China First Glacier Inventory (Liu et al. 2000), which recorded glacier data in the 1960s, there were 124 glaciers above the YHS with a total area of $37.95 \mathrm{~km}^{2}$. The maximum glacier area was $3.28 \mathrm{~km}^{2}$, and the minimum glacier area was $0.02 \mathrm{~km}^{2}$, with a mean of $0.31 \mathrm{~km}^{2}$. The UG1 is a northeast-facing glacier valley that has the 


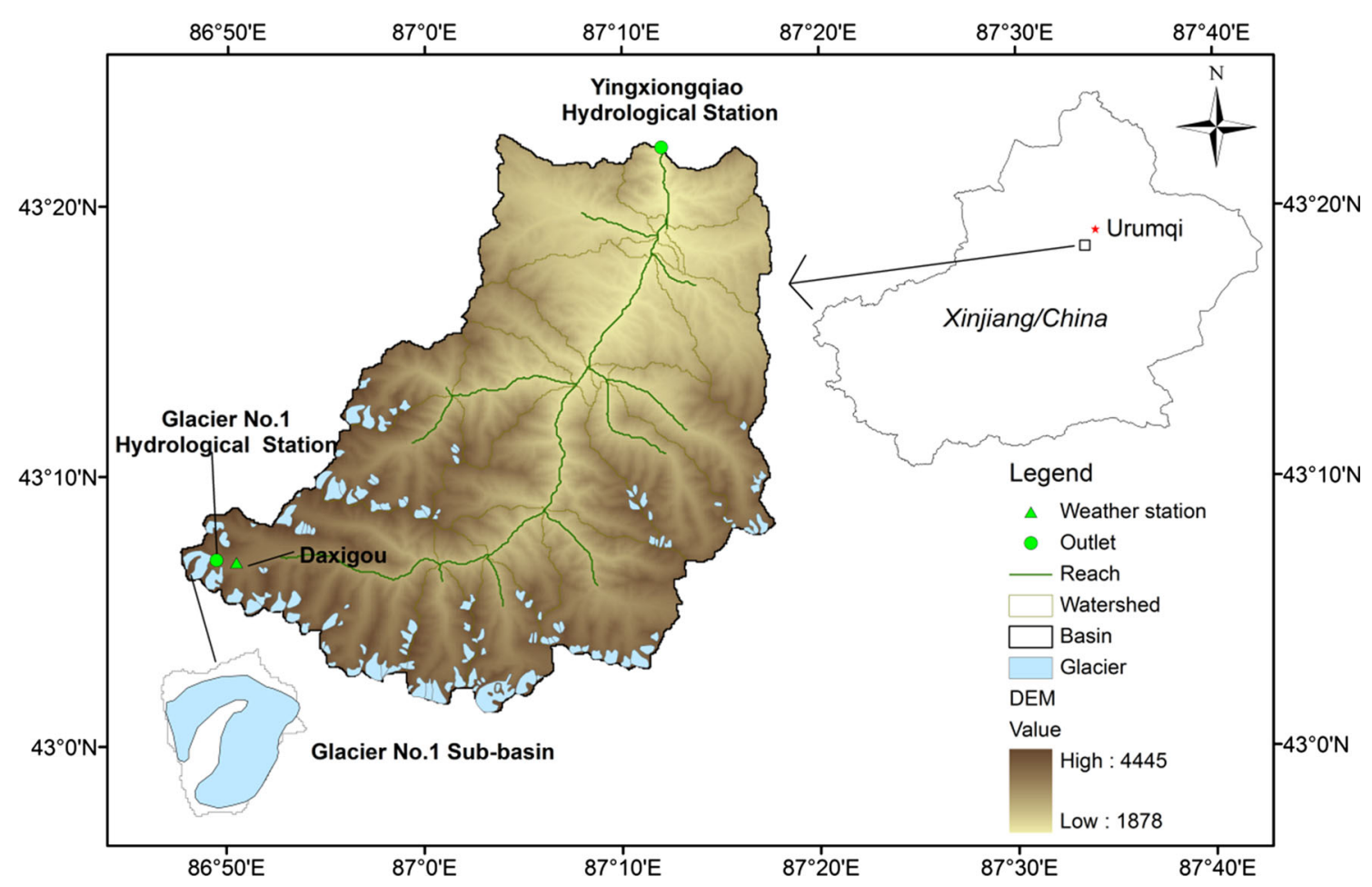

Fig. 1 Location map of the headwater of the Urumqi River Basin in Xinjiang Uygur Autonomous Region, China

longest record of observed data in China and has been cataloged in the World Glacier Monitoring Service (WGMS) network (Zhang et al. 2014). The drainage area of the UG1 is $3.34 \mathrm{~km}^{2}$ above the Glacier No. 1 Hydrological Station (GHS) (Fig. 1).

\section{SWAT model}

The SWAT model (Arnold et al. 1993) is widely used to simulate landscape and streamflow processes in watersheds. It is a continuous-time, semi-distributed, processbased river basin model that uses the concept of Hydrological Response Units (HRUs), which are lumped land areas within each sub-basin that are comprised of unique land cover, soil, and management combinations. The SWAT model can simulate rainfall and snow melt runoff processes, but not including glacier module.

To enable the SWAT model to simulate glacio-hydrological processes, Luo et al. (2013) proposed Glacier Hydrological Response Units (GHRUs) as a method to simulate the glacier mass balance and dynamics of individual glaciers. The GHRU approach uses a volume-area scaling relation (Chen and Ohmura 1990) to calculate the area of each glacier:

$V=m A^{n}$

where $V\left(\mathrm{~m} \mathrm{~km}^{2}\right)$ is glacier volume; $A\left(\mathrm{~km}^{2}\right)$ is glacier area; $m$ and $n$ are constants.
The degree-day method is used to calculate ice melt. Following Lutz et al. (2014), the basin-wide runoff calculated by the model is divided into the following four parts: glacier melt, snow melt, rainfall runoff and baseflow. Glacier melt consists of ice melt, supraglacial snowmelt and rainfall-induced runoff on ice. Snow melt consists of the snow melt water released from the snow storage, where sublimation and evaporation are subtracted. Rainfall runoff consists of the surface runoff and lateral flow released from soil water storage generated by rainfall. Baseflow is released from groundwater storage. Runoff from HRUs and GHRUs are routed to the outlets of the sub-basins and then to the outlet of the catchment via a channel system with transmission losses deducted.

The performance of simulated streamflow was evaluated using the Nash-Sutcliffe efficiency (NSE) (1970) and percent bias (PBIAS) (Moriasi et al. 2007). NSE and PBIAS are calculated as:

$\mathrm{NSE}=1-\left[\frac{\sum_{i=1}^{n}\left(Q_{i}^{\text {obs }}-Q_{i}^{\text {sim }}\right)^{2}}{\sum_{i=1}^{n}\left(Q_{i}^{\text {obs }}-Q^{\text {mean }}\right)^{2}}\right]$
PBIAS $=\left[\frac{\sum_{i=1}^{n}\left(Q_{i}^{\text {obs }}-Q_{i}^{\text {sim }}\right) \cdot 100}{\sum_{i=1}^{n} Q_{i}^{\text {obs }}}\right]$

where $Q_{i}^{\text {obs }}$ is the $i$ th streamflow observation; $Q_{i}^{\text {sim }}$ is the $i$ th simulated streamflow value; $Q^{\text {mean }}$ is the mean observed streamflow; and $n$ is the total number of observations. 
NSE indicates how well the plot of observed versus simulated data fits the 1:1 line. PBIAS measures the average tendency of the simulated data to be larger or smaller than their observed counterparts. Moriasi et al. (2007) also rated the performance of the streamflow statistics as 'very good', 'good', 'satisfactory' or 'unsatisfactory' using $0.75<\mathrm{NSE}$ $\leq 1.0,0.65<\mathrm{NSE} \leq 0.75,0.50<\mathrm{NSE} \leq 0.65$, or $\mathrm{NSE}$ $\leq 0.50$, respectively; or by PBIAS $< \pm 10 \%, \pm 10 \% \leq$ PBIAS $< \pm 15 \%, \pm 15 \% \leq$ PBIAS $< \pm 25 \%$, or PBIAS $\geq \pm 25 \%$, respectively.

\section{Data set}

The Digital Elevation Model (DEM) was extracted from the Shuttle Radar Topography Mission (SRTM) with a $90 \mathrm{~m}$ resolution.

The glacier maps were obtained from the China First Glacier Inventory and Second Glacier Inventory released by the Cold and Arid Regions Science Data Center (Liu et al. 2000, 2015). The land cover data were obtained from the Global Land Cover Map (GlobCover 2009) with a $300 \mathrm{~m}$ resolution. The saw land cover was reclassified by the 2001 National Land Cover Data (NLCD 2001) in ArcSWAT (Winchell et al. 2007). Excluding the GHRU portion, the main types of reclassified land cover were mixed forest (FRST), grassland (RNGE) and barren land (SWRN), accounting for $21.7,39.3$ and $30.8 \%$ of the basin area, respectively (Fig. S1).

The Harmonized World Soil Database V 1.2 (HWSD) provided by the International Institute for Applied Systems Analysis and Food and Agriculture Organization of the United Nations with a 1:1,000,000 scale was extracted to generate the soil layer. Each soil unit of HWSD includes texture, depth, bulk density, organic carbon content and electrical conductivity, which can be used directly in the SWAT soil database. Some important parameters, such as the available water capacity and saturated hydraulic conductivity, were calculated using the percentages of sand, silt and clay provided in the database. The classified soil types were calcic chernozems, glacier/permanent snow, haplic greyzems, gelic leptosols and mollic leptosols, accounting for $6.2,10.6,4.6,44.6$ and $34.1 \%$, respectively (Fig. S2).

Daxigou is a base meteorological station with an elevation of $3543.8 \mathrm{~m}$ in the URB (Fig. 1). During 1959-2006, the average annual temperature in Daxigou was $-5.1{ }^{\circ} \mathrm{C}$ (maximum of $0{ }^{\circ} \mathrm{C}$, minimum of $-9.0{ }^{\circ} \mathrm{C}$ ). The mean annual precipitation was approximately $450 \mathrm{~mm}, 70 \%$ of which occurred during summer months.

The observed monthly streamflow data at YHS from 1964 to 1989 was obtained from China's Hydrological Yearbook compiled for the Xinjiang autonomous prefecture.

\section{Model setup}

The main river channel and tributaries were generated based on the DEM, and the basin was delineated into 21 sub-basins (Fig. 1). The generation of GHRUs and HRUs was based on glacier, land use and soil type maps. The drainage area of each GHRU consisted of both icecovered and non-ice-covered sections. The drainage boundaries were delineated based on the DEM overlaid with glacier maps. HRUs were generated from land cover and soil maps. Among the 21 sub-basins, 11 subbasins consisted of glaciers. The initial glacier area ratios among the sub-basins ranged from 0.36 to $14.83 \%$. A total of 150 HRUs were generated from the 21 sub-basins.

\section{Climate change projections and downscaling method}

To provide a multi-level assessment of future glacio-hydrological processes, the outputs from the latest general circulation models (GCMs) in the phase fifth of the Coupled Model Intercomparison Project (CMIP5) (Taylor et al. 2012) from 2006 to 2100 were chosen to force the glacier-enhanced SWAT model. The five best models were selected (Table 1) from 39 models based on their ability to accurately simulate the annual average temperature and precipitation relative to the observed average temperature and precipitation in the northwest, arid regions of China (Wu et al. 2014). The representative concentration pathways (RCPs) are a set of greenhouse gas concentration and emissions pathways designed to support the research on impacts and potential policy responses to climate change (van Vuuren et al. 2011). Climate change projections based on RCPs cover a wide range of outcomes. Specifically, the RCP 2.6 (peak in radiative forcing at about $3 \mathrm{~W} / \mathrm{m}^{2}$ before 2100 and decline), the RCP 4.5 (stabilization without overshoot pathway to $4.5 \mathrm{~W} / \mathrm{m}^{2}$ at stabilization after 2100 ) and the RCP 8.5 (rising radiative forcing pathway leading to $8.5 \mathrm{~W} / \mathrm{m}^{2}$ in 2100) scenarios were used in this study.

The delta change approach (Diaz-Nieto and Wilby 2005; Chen et al. 2011) was employed to generate future time series of daily air temperature and precipitation. This method adjusted the observed time series by adding the difference in temperature and multiplying the ratio of precipitation between future and present climates, as simulated by the GCMs. The mean temperature/precipitation of DMS and GCMs from 1964 to 2005 were used to calculate the additive/multiplicative change factors, and the factors were then applied to future values from 2006 to 2010. 
Table 1 Information on the selected CMIP5 climate models

\begin{tabular}{lll}
\hline Model & Institute, country & Horizontal resolution (lat $\times$ lon) \\
\hline CCSM4 & National Center for Atmospheric Research, USA & $0.94 \times 1.25$ \\
CNRM-CM5 & Centre National de Recherches Meteorologiques, France & $1.4 \times 1.4$ \\
IPSL-CM5A-LR & Institut Pierre-Simon Laplace, France & $1.875 \times 3.75$ \\
MIROC5 & Atmosphere and Ocean Research Institute, National Institute for Environmental & $1.4 \times 1.4$ \\
& $\quad$ Studies, and Japan Agency for Marine-Earth Science and Technology & $1.875 \times 1.875$ \\
MPI-ESM-LR & Max Planck Institute for Meteorology, Germany & \\
\hline
\end{tabular}

\section{Results}

\section{Model parameterization and performance evaluation}

The model was calibrated and validated using observed streamflow data. The first 2 years (1964-1965) were a warm-up period and the other available streamflow data were divided into two sets: 12 years (1966-1977) for calibration and 12 years for validation (1978-1989). Additionally, the UG1 was calibrated by the observed mass balance.

Monthly lapse rates were used to adjust temperature and precipitation in different elevation bands. The temperature lapse rates for the URB were obtained from published literature for January to December $(-3.0,-3.2,-4.1,-5.3$, $-6.0, \quad-5.3, \quad-6.0, \quad-5.7, \quad-5.8, \quad-4.2, \quad-3.3$ and $-2.7{ }^{\circ} \mathrm{C} \mathrm{km}^{-1}$, respectively) (Cui et al. 2013). Monthly precipitation lapse rates were calibrated by trial and error, using a step of $10 \mathrm{~mm} \mathrm{~km}^{-1}$ to reach the best performance of simulated streamflow. The final calibrated values for January to December were 10, 10, 20, 30, 70, 120, 160, $110,40,20,20$ and $10 \mathrm{~mm} \mathrm{~km}^{-1}$, respectively.
Table 2 lists the most sensitive parameters of the glacier-enhanced SWAT model for the URB and similar study basins in the Tianshan Mountains (Luo et al. 2013; Gan et al. 2015; Ma et al. 2015). Ice and snow parameterization are crucial for glacier dynamics and melt water processes. As the UG1 was the only measured glacier, the melt factors for snow of June 21 and December 21 were set at $3.5 \mathrm{~mm}^{\circ} \mathrm{C}^{-1} \mathrm{day}^{-1}$ and $2.5 \mathrm{~mm}^{\circ} \mathrm{C}^{-1} \mathrm{day}^{-1}$, respectively, based on the reported value of $3.1 \mathrm{~mm}^{\circ} \mathrm{C}^{-1} \mathrm{day}^{-1}$ of the UG1 (Liu et al. 1998). The melt factors for ice were first referenced to the documented values of the UG1 (1.12-14.3 $\mathrm{mm}^{\circ} \mathrm{C}^{-1} \mathrm{day}^{-1}$ for the East Branch and 0.98-13.84 $\mathrm{mm}^{\circ} \mathrm{C}^{-1} \mathrm{day}^{-1}$ for the West Branch during 1983-2004) (Cui et al. 2013) and then adjusted by trial and error based on the observed mass balance of the UG1. The final calibrated GMFMX and GMFMN for the UG1 were 5.0 and $7.9 \mathrm{~mm}^{\circ} \mathrm{C}^{-1}$ day $^{-1}$, respectively. As the mass balances of other glaciers were not observed, GMFMX and GMFMN for other glaciers were calculated based on the individual area change derived from the two glacier inventories. The constants $m$ and $n$ in the volume-area scaling relation were derived from the records of the First Glacier Inventory of China based on regression analysis.

Table 2 Calibrated key parameters of glacier-enhanced SWAT model in the Urumqi River Basin

\begin{tabular}{|c|c|c|c|c|c|}
\hline Variable name & Description & Unit & $\begin{array}{l}\text { Range of } \\
\text { values }\end{array}$ & $\begin{array}{l}\text { Calibrated } \\
\text { values }\end{array}$ & $\begin{array}{l}\text { Sensitivity } \\
\text { ranking }\end{array}$ \\
\hline GWQMN & Threshold water level in shallow aquifer & $\mathrm{mm}$ & $0-1000$ & 100 & 1 \\
\hline $\mathrm{CN} 2$ & SCS runoff curve number for moisture condition II & - & $\pm 10 \%$ & -0.04 & 2 \\
\hline Sol_Awc & Available water capacity & $\mathrm{mm} / \mathrm{mm}$ & $\pm 25 \%$ & $5 \%$ & 3 \\
\hline CH_K2 & Effective hydraulic conductivity & $\mathrm{mm} \mathrm{h}^{-1}$ & $0-150$ & 55 & 4 \\
\hline$\delta_{\mathrm{gw}, \mathrm{sh}}$ & Delay time of shallow aquifer geologic formations & days & $0-31$ & 20 & 5 \\
\hline$\delta_{\mathrm{gw}, \mathrm{dep}}$ & Delay time of the deep aquifer geologic formations & days & $0-150$ & 125 & 6 \\
\hline$\alpha_{\mathrm{gw}, \mathrm{sh}}$ & Recession constant of shallow aquifer & - & $0-1$ & 0.5 & 7 \\
\hline$\alpha_{\mathrm{gw}, \mathrm{dp}}$ & Recession constant of deep aquifer & - & $0-1$ & 0.05 & 8 \\
\hline SMFMX & Melt factor for snow on June 21 & $\mathrm{~mm}^{\circ} \mathrm{C}^{-1} \mathrm{day}^{-1}$ & $0-10$ & 3.5 & 9 \\
\hline SMFMN & Melt factor for snow on December 21 & $\mathrm{~mm}{ }^{\circ} \mathrm{C}^{-1} \mathrm{day}^{-1}$ & $0-10$ & 2.5 & 10 \\
\hline GMFMX & Melt factor for ice on June 21 & $\mathrm{~mm}^{\circ} \mathrm{C}^{-1}$ day $^{-1}$ & $0-20$ & $2.5-17.4$ & 11 \\
\hline GMFMN & Melt factor for ice on December 21 & $\mathrm{~mm}^{\circ} \mathrm{C}^{-1}$ day $^{-1}$ & $0-20$ & $1.6-10.8$ & 12 \\
\hline
\end{tabular}


Fig. 2 Comparison of simulated to measured streamflow at the calibration period (a) and validation period (b) at the Yingxiongqiao Hydrological Station
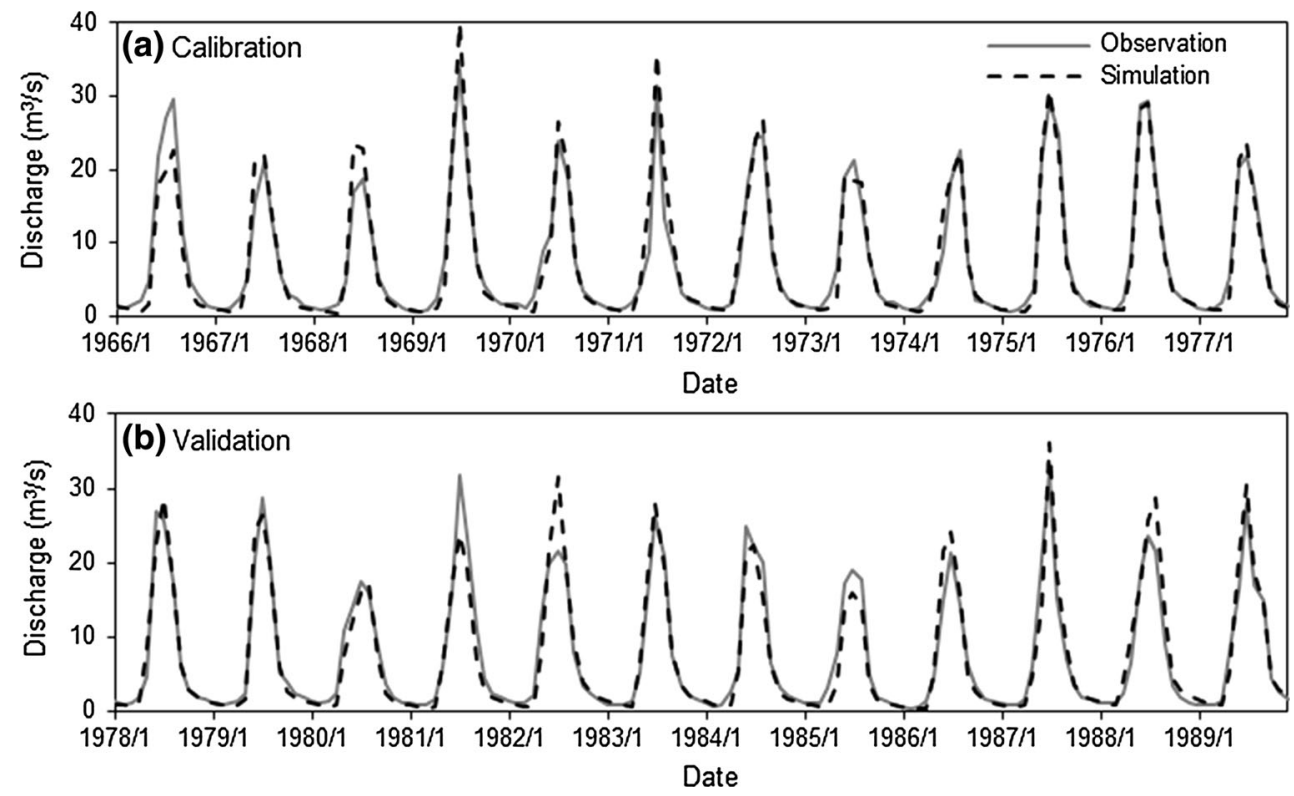

The estimated constants $m$ and $n$ for URB were 41.6 and 1.383 , respectively.

The initial values for the parameters $\delta_{\mathrm{gw}, \mathrm{sh}}, \alpha_{\mathrm{gw}, \mathrm{sh}}, \delta_{\mathrm{gw}, \mathrm{dep}}$ and $\alpha_{\mathrm{gw}, \mathrm{dp}}$ of the two-reservoir baseflow approach were set as $15,0.4,127$ and 0.05, referencing the values in the Manas River Basin (Luo et al. 2012). Other parameters were first kept at the SWAT default values and manually adjusted until an acceptable fit between the measured and simulated streamflow was obtained. The sensitivity ranking of each parameter for the URB streamflow is also listed in Table 2.

Comparisons of the simulated and the observed hydrographs are presented in Fig. 2. Values of NSE for monthly simulated streamflow at the calibration and validation periods were 0.94 and 0.93 , respectively; both of which were ranked as 'very good' (Moriasi et al. 2007). The values of PBIAS during the calibration and validation periods were also ranked as 'very good' at 1.0 and $2.1 \%$, respectively. The simulated annual mean discharge at GHS from 1980 to 2005 was $680 \mathrm{~mm}$, which was close to the observed value of $660 \mathrm{~mm}$ (Li et al. 2010).

The biases between simulated streamflow derived from observed weather data and from each GCM projection are shown in Fig. S3. The biases of CCSM4, CNRM-CM5, IPSL-CM5A-LR, MPI-ESM-LR and MIROC5 were $6.1 \%$, $-1.6,8.9,1.8$ and $4.5 \%$, respectively. The five GCMpredicted streamflow all reliably captured the seasonal patterns of discharge.

The simulated total glacier area was reduced by approximately $33 \%$ (1964-2005), which was similar to the loss of roughly $37 \%$ (1964-2007) calculated from the two maps of glacier inventories. The simulated area shrinkage of UG1 was $0.26 \mathrm{~km}^{2}$ during 1964-2005, comparable to the observed $0.36 \mathrm{~km}^{2}$ loss during 1964-2007 from the glacier inventories. Overall, the simulated cumulative mass balance of UG1 captured the long-term patterns in the observed values (Fig. S4).

\section{Changes in projected climate}

Averages over the three following periods were obtained for the five GCMs ensembles: the baseline period (1966-1995), the near future (2016-2045) and the far future (2066-2095). These specific periods were chosen to analyze the potential intra- and inter-annual changes under RCP 2.6, RCP 4.5 and RCP 8.5. Changes in temperature and precipitation for the future periods relative to the baseline period are shown in Table 3. The temperature increases under RCP 2.6 in the near future and far future periods by 2.2 and $2.3{ }^{\circ} \mathrm{C}$, respectively. However, the increases under RCP 4.5 and RCP 8.5 are relatively larger. Additionally, the temperature changes in the near future period are not clearly predicted among the three RCPs, but the increases for the far future are significant. The precipitation changes under all RCPs show an increase in the future, with a range of 21.6-25.5\% for the near future and 16.8-22.2\% for the far future, respectively. The increased magnitudes are nearly identical within the year under all RCPs in the near future, while larger increases are predicted in the far future (Fig. 3). Furthermore, the precipitation mainly increases during cold and warm months.

\section{Changes in projected glaciers}

The predicted changes in glacier area are shown in Table 4. The total glacier area continues to decrease with approximately $70 \%$ loss by 2045 relative to 1964 under all three 
Table 3 Changes in precipitation and temperature on averages of the five GCMs for the two future periods relative to the baseline period of 1966-1995 in the Urumqi River Basin

\begin{tabular}{llllllll}
\hline & \multicolumn{2}{l}{ Near future (2016-2045) } & & \multicolumn{2}{l}{ Far future (2066-2095) } \\
\cline { 2 - 3 } \cline { 6 - 7 } & RCP 2.6 & RCP 4.5 & RCP 8.5 & & RCP 2.6 & RCP 4.5 & RCP 8.5 \\
\hline Temperature $\left({ }^{\circ} \mathrm{C}\right)$ & +2.2 & +2.1 & +2.4 & +2.3 & +3.4 & +5.8 \\
Precipitation $(\%)$ & +21.6 & +25.5 & +24.9 & +20.4 & +22.2 & +16.8 \\
\hline
\end{tabular}

Fig. 3 Comparisons of average monthly precipitation and temperature distributions on averages of the five GCMs in three RCPs relative to the baseline period of 1966-1995 in the Urumqi River Basin
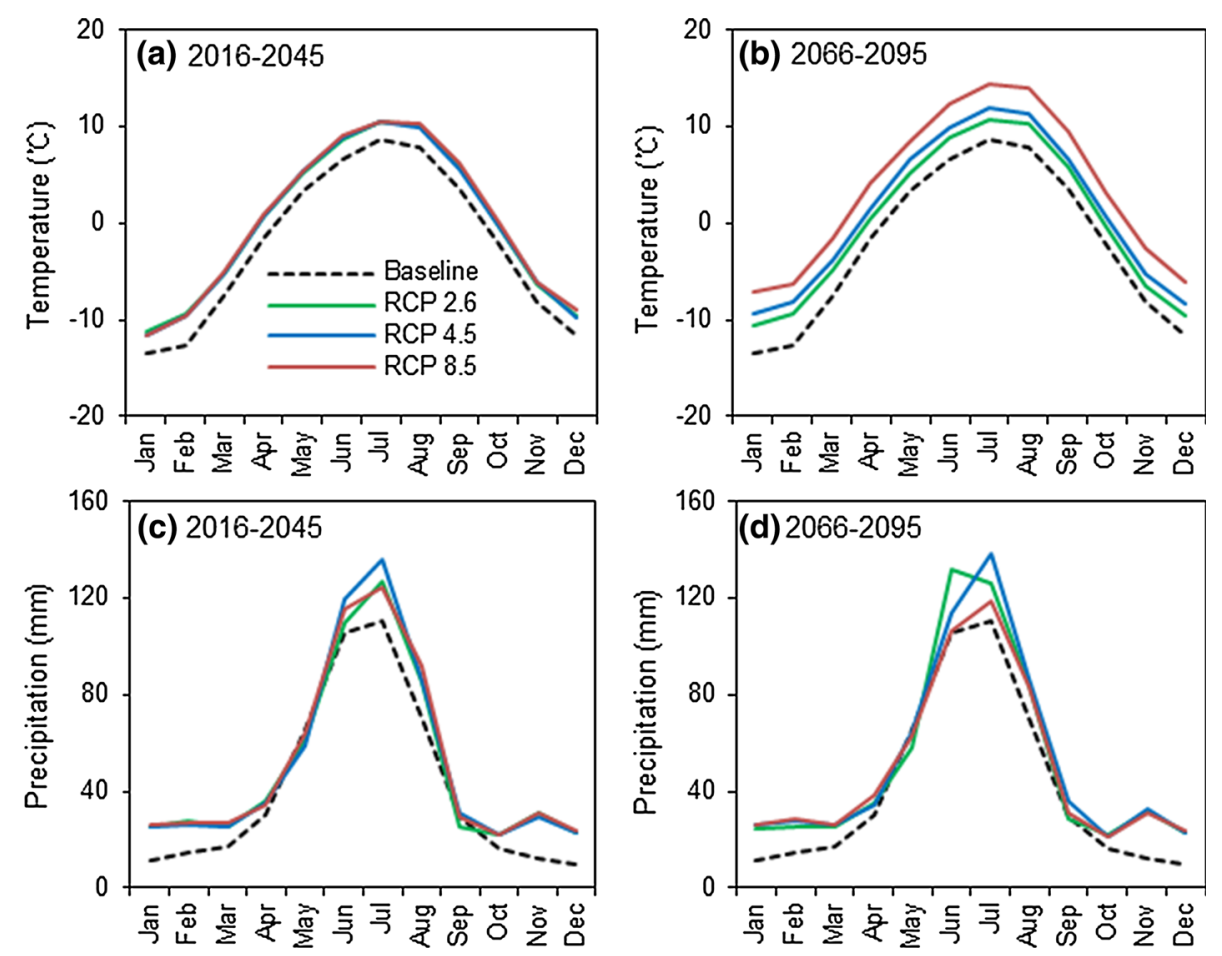

Table 4 Changes in glacier area on averages of the five GCMs by 2045 and 2095 relative to 1964 in the Urumqi River Basin

\begin{tabular}{|c|c|c|c|c|c|c|c|c|}
\hline & \multirow[t]{2}{*}{ Size $\left(\mathrm{km}^{2}\right)$} & \multirow{2}{*}{$\begin{array}{l}\text { Area }\left(\mathrm{km}^{2}\right) \\
\text { In } 1964\end{array}$} & \multicolumn{2}{|c|}{ RCP $2.6(\%)$} & \multicolumn{2}{|c|}{ RCP $4.5(\%)$} & \multicolumn{2}{|c|}{ RCP $8.5(\%)$} \\
\hline & & & Ву 2045 & By 2095 & By 2045 & By 2095 & Вy 2045 & By 2095 \\
\hline Glacier No. 1 & 1.94 & 1.94 & -54.9 & -79.8 & -56.3 & -90.6 & -61.1 & -99.7 \\
\hline \multirow[t]{4}{*}{ Urumqi River Basin } & G1 $(<0.5)$ & 17.75 & -80.9 & -89.5 & -82.0 & -94.8 & -84.6 & -99.1 \\
\hline & G2 $(0.5-1)$ & 11.40 & -66.3 & -84.1 & -67.7 & -91.5 & -70.8 & -98.4 \\
\hline & G3 $(\geq 1)$ & 8.80 & -54.0 & -72.8 & -55.1 & -81.5 & -58.0 & -92.1 \\
\hline & All & 37.95 & -70.3 & -84.0 & -71.5 & -90.8 & -74.3 & -97.3 \\
\hline
\end{tabular}

RCPs. The simulated glacier areas of URB by 2095 under RCP 2.6, RCP 4.5 and RCP 8.5 are $6.1,3.5$ and $1.0 \mathrm{~km}^{2}$, respectively. Glaciers are expected to retreat rapidly under warming conditions in all RCPs; however, the significantly increased precipitation that contributes to glacier accumulation partly compensates for the warming effect in the near future. In particular, RCP 8.5 is an extreme scenario with higher temperature and less precipitation, and the glaciers nearly all disappear by the end of this century under that scenario.

Table 4 also indicates that the small-sized, grouped glaciers show a rapid shrinkage rate, both in the historical period and future scenarios. The glacier area with small sizes $\left(<0.5 \mathrm{~km}^{2}\right)$ under RCP 2.6 is reduced approximately $90 \%$ by 2095 , while the retreat for the group $\left(\geq 1 \mathrm{~km}^{2}\right)$ is only $70 \%$ during the same period. This is because small 

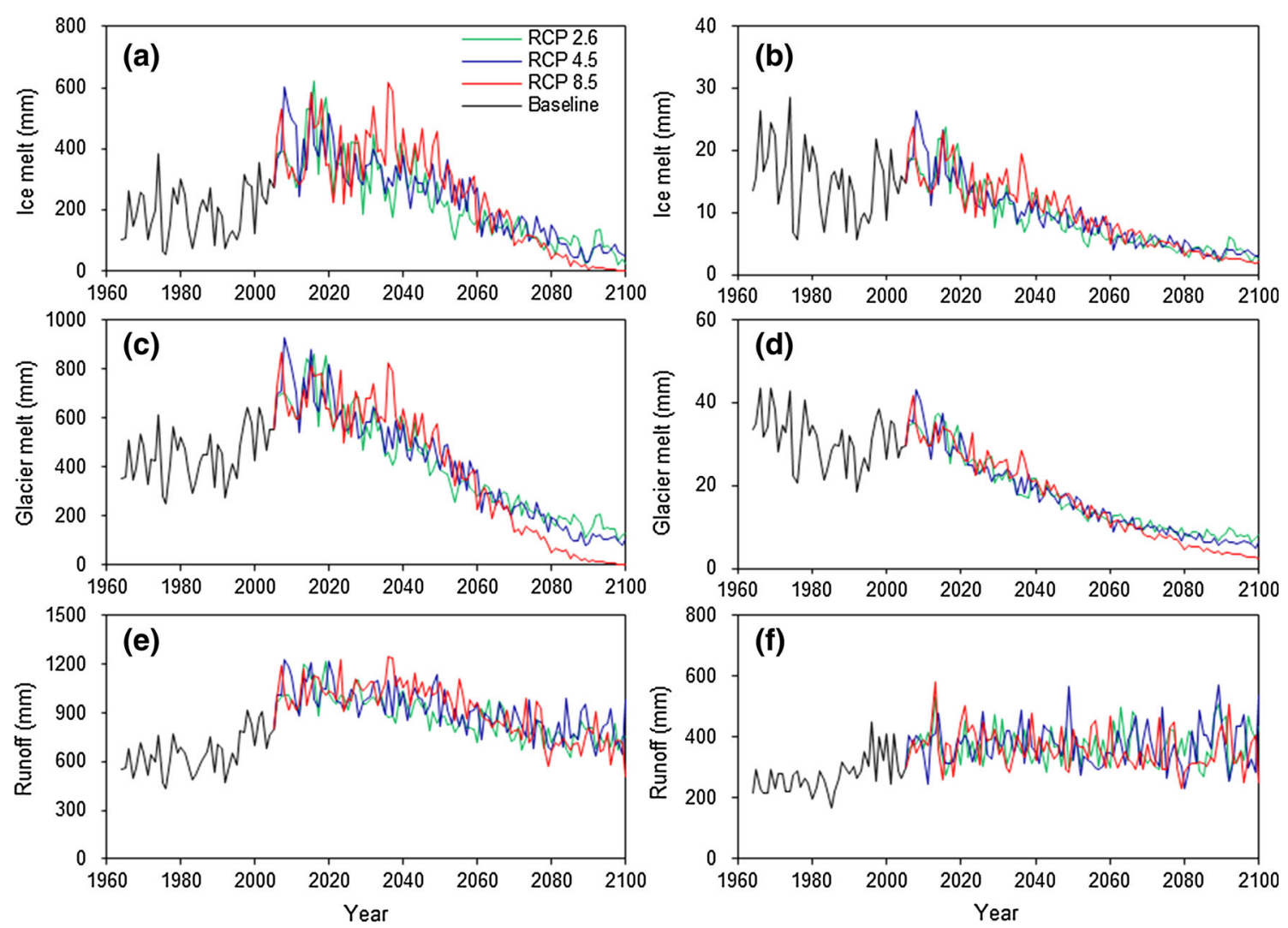

Fig. 4 Inter-annual ice melt and glacier melt and runoff on averages of the five GCMs for historical period and future scenarios in the Glacier No. 1 sub-basin (a, c, e) and Urumqi River Basin $(\mathbf{b}, \mathbf{d}, \mathbf{f})$

glaciers are more sensitive to temperature and have quicker response times to climate change. The area of change for UG1 under the three RCPs is consistent with its size group $\left(\geq 1 \mathrm{~km}^{2}\right)$.

\section{Changes in projected melt water and runoff}

\section{Inter-annual changes}

The annual ice and glacier melt and runoff from the UG1 sub-basin and URB exhibit different trends, both in historical period and future scenarios (Fig. 4).

In the UG1 sub-basin, the ice and glacier melt are stable before 1995 and significantly increase under the three RCPs. It is expected to reach peak water and then significantly decrease in the following years, especially under RCP 8.5. In contrast, the ice and glacier melt from URB display a remarkable decrease before 1995, and then linearly decrease in the future.

The total annual runoff from the UG1 sub-basin and URB both significantly increase in the historical period. The runoff from the UG1 sub-basin remains high during 2006-2010 and gradually declines under the three RCPs. Nevertheless, the runoff from URB remains stable under
RCP 2.6 and RCP 4.5, with only a slight decrease under RCP 8.5.

\section{Intra-annual changes}

The intra-annual distributions of mean ice melt, glacier melt and runoff from the UG1 sub-basin are shown in Fig. 5. During the baseline period, the ice melt from JulySeptember accounts for $91.7 \%$ of its annual amount. The GCM-predicted rise in temperature prolongs the melt season and intensifies the melt water. The predicted ice melt significantly increases in the near future (Fig. 5a), especially under RCP 8.5 (Table 5). Nevertheless, it significantly decreases in the far future (Fig. 5b). Furthermore, during July-September, the ice melt accounts for 86.2, 86.9 and $85.6 \%$ of its annual volume under RCP 2.6, RCP 4.5 and RCP 8.5 in near future, respectively; however, the proportion is only $79.7 \%$ in the far future under RCP 8.5.

The glacier melt from the UG1 sub-basin displays a relatively slow increase and a rapid decline compared to ice melt (Fig. 5c, d). The intra-annual distribution does not obviously change in the near future compared with the baseline period. The glacier melt significantly decreases in the far future, especially under RCP 8.5. It was also found 
Fig. 5 Intra-annual ice melt and glacier melt and runoff on averages of the five GCMs for the baseline period of 1966-1995 and future scenarios in the Glacier No. 1 sub-basin
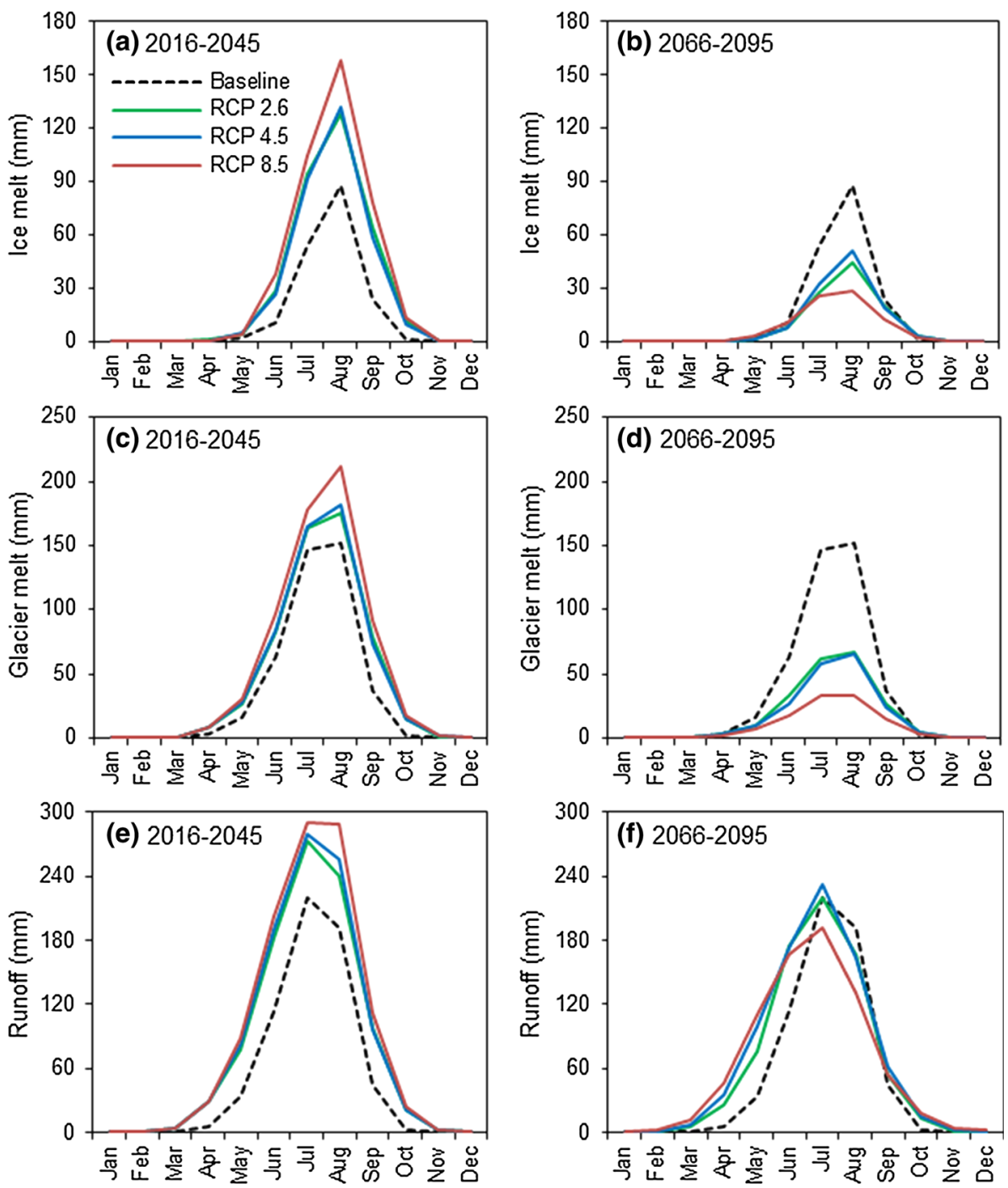

Table 5 Changes melt water and runoff on averages of the five GCMs for the two periods of 2016-2045 and 2066-2095 relative to the baseline period of 1966-1995 under three RCPs

\begin{tabular}{|c|c|c|c|c|c|c|c|}
\hline \multirow[t]{2}{*}{ Scale } & \multirow[t]{2}{*}{ Element } & \multicolumn{3}{|c|}{ Near future (2016-2045) (mm) } & \multicolumn{3}{|c|}{ Far future $(2066-2095)(\mathrm{mm})$} \\
\hline & & RCP 2.6 & RCP 4.5 & RCP 8.5 & RCP 2.6 & RCP 4.5 & RCP 8.5 \\
\hline \multirow[t]{3}{*}{ Glacier No. 1 sub-basin } & Ice melt & +169.5 & +158.0 & +224.7 & -75.3 & -74.8 & -108.9 \\
\hline & Glacier melt & +161.3 & +155.3 & +222.3 & -216.9 & -247.9 & -328.2 \\
\hline & Runoff & +371.5 & +390.8 & +454.7 & +158.8 & +200.4 & +153.7 \\
\hline \multirow[t]{4}{*}{ Urumqi River Basin } & Ice melt & -2.5 & -3.0 & -1.0 & -10.6 & -10.6 & -10.9 \\
\hline & Glacier melt & -7.5 & -7.8 & -5.6 & -21.5 & -22.6 & -24.7 \\
\hline & Snow melt & +26.5 & +22.3 & +23.2 & +28.3 & +21.4 & +4.6 \\
\hline & Runoff & +102.5 & +120.2 & +117.9 & +111.5 & +120.1 & +82.7 \\
\hline
\end{tabular}

that the increase of glacier melt is slightly less than ice melt in the near future and the decrease is much greater in the far future, as the glacier melt is partly due to supraglacial snowmelt.

The predicted runoff from UG1 sub-basin lasts a longer time in the near future due to the intensified snow and glacier melts (Fig. 5e, f). The predicted runoff increases under the three RCPs from 371.5 to $454.7 \mathrm{~mm}$ and 153.7-200.4 $\mathrm{mm}$ for the near and far future scenarios, relative to the baseline period (Table 5). The peak runoff in the far future is shifted forward approximately 1 month.

In URB, the predicted future ice melt shows an obvious decrease during peak ablation months (July-August) (Fig. 6a, b), especially in the far future. The annual mean 
Fig. 6 Intra-annual ice melt, glacier melt, snow melt and river runoff on averages of the five GCMs for baseline period and future scenarios in the Urumqi River Basin
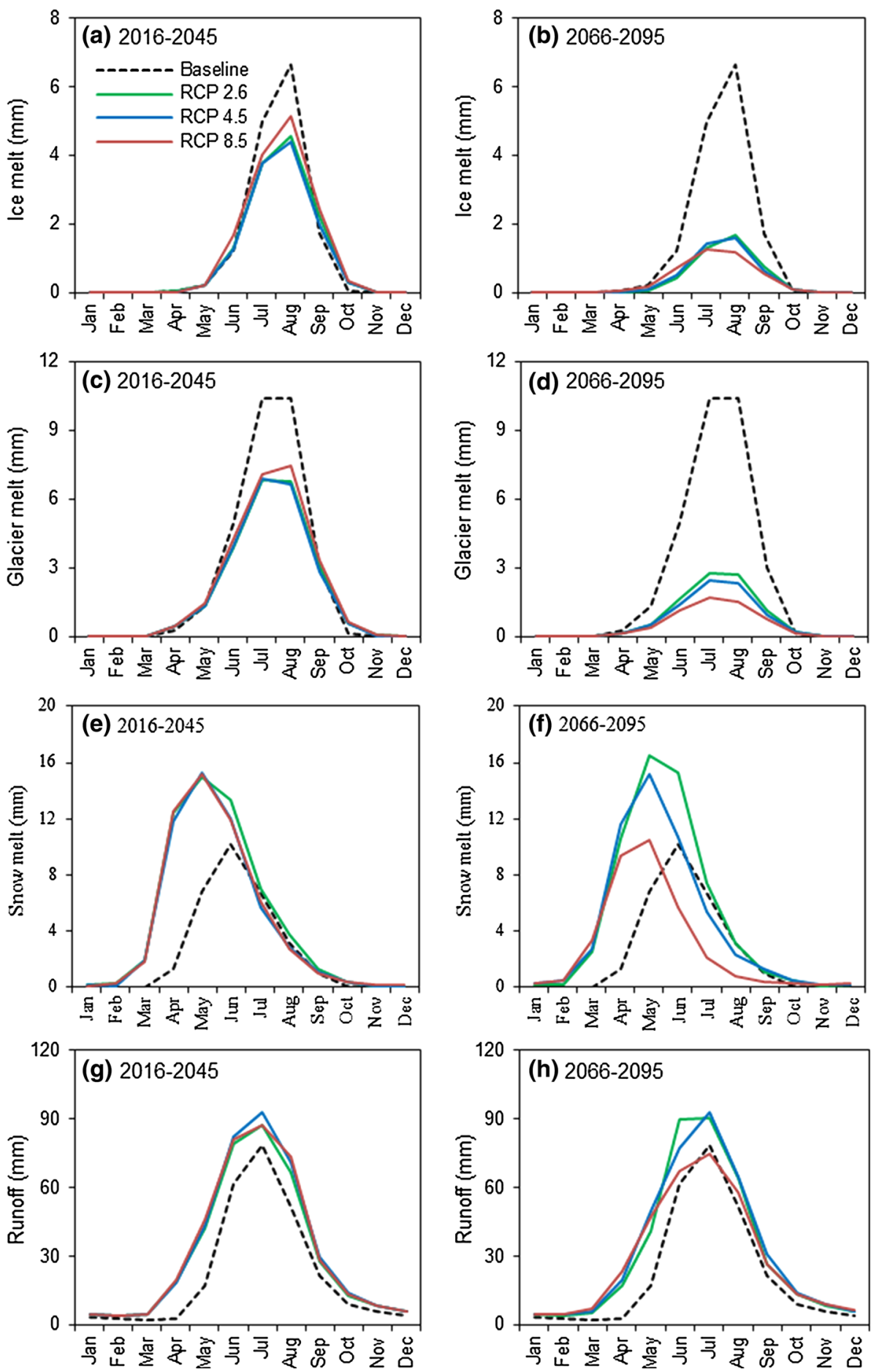

ice melt decreases less than $3 \mathrm{~mm}$ for the near future and approximately $11 \mathrm{~mm}$ for the far future, respectively (Table 5). The glacier melt shows a similar intra-annual variation with ice melt (Fig. 6c, d), and the decrease is in the range of -5.6 to $-7.8 \mathrm{~mm}$ and -21.5 to $-24.7 \mathrm{~mm}$ for near future and far future scenarios, respectively. The future distribution of snow melt also significantly changes.
The peak water of snow melt moves forward more than 1 month (Fig. 6e, f). The river runoff (Fig. 6g, h), increases from 102.5 to $120.2 \mathrm{~mm}$ for near future scenarios and 82.7-120.1 mm for far future scenarios relative to the baseline period, due to the increased precipitation. The earlier water yield in spring is mainly attributed to the earlier snow melt. 


\section{Discussion}

\section{Peak water}

It is worth noting that the peak water of ice and glacier melt in the UG1 sub-basin is captured from GCM predictions; however, this phenomenon is not apparent at the basin scale. From a hydrological point of view, the peak water may be mainly related to potential changes in the glacier reserve, temperature and precipitation (Baraer et al. 2012; Sorg et al. 2014). The water equivalent from the glacier-covered area (glacier melt in this study) is estimated from supraglacial snowmelt, ice melt and rainfall-induced runoff on ice. The supraglacial snowmelt is affected by both temperature and precipitation, and the amount largely depends on the precipitation distribution. The ice melt from the loss of glacier volume lags behind supraglacial snowmelt, is mainly influenced by temperature, and is an additional water yield to river runoff that could stabilize the runoff hydrograph (Jansson et al. 2003). The rainfall-induced runoff rapidly drains to the river system in warm seasons (Collins 1998). Li et al. (2010) found a larger increase in observed runoff in the UG1 sub-basin (54\% glacierization) than that in the Zongkong sub-basin (18.5\% glacierization). In this study, the UG1 sub-basin was treated as a huge glacierized subbasin and the simulated glacier area only decreased by $13 \%$ as of 2005. Nevertheless, approximately $33 \%$ of total glacier area (4.1\% glacierization) in the URB has vanished in the historical period. As the GCM-predicted temperature continues to increase, the ice melt from the negative mass balance contributes to the runoff increase of the UG1 sub-basin, and it approaches to peak water in the near future. Although the higher temperatures after 1995 intensified ice melt, the drastically reduced glacier volume could not provide sustainable water for long period at the basin scale.

At the outlet of a basin, the glacier melt is a sum of the melt water processes from individual glaciers. All glaciers in the basin are anticipated to undergo similar climate change in terms of a long period. Nevertheless, each glacier may exhibit its own melt water characteristic in response to climate change. The issue of the melt water change from glaciers within certain size classes should be stressed because grouped glaciers are expected to respond similarly to climate change. The results showed that the three glacier groups exhibit clearly different decadal variations in ice and glacier melt (Fig. 7). The ice and glacier melt of G1 rapidly decrease while G2 and G3 show similar decadal variations under all scenarios. The ice and glacier melt from UG1 is only a part of its group (G3), and it is expected to reach its peak water before decreasing rapidly. The peak water from the three
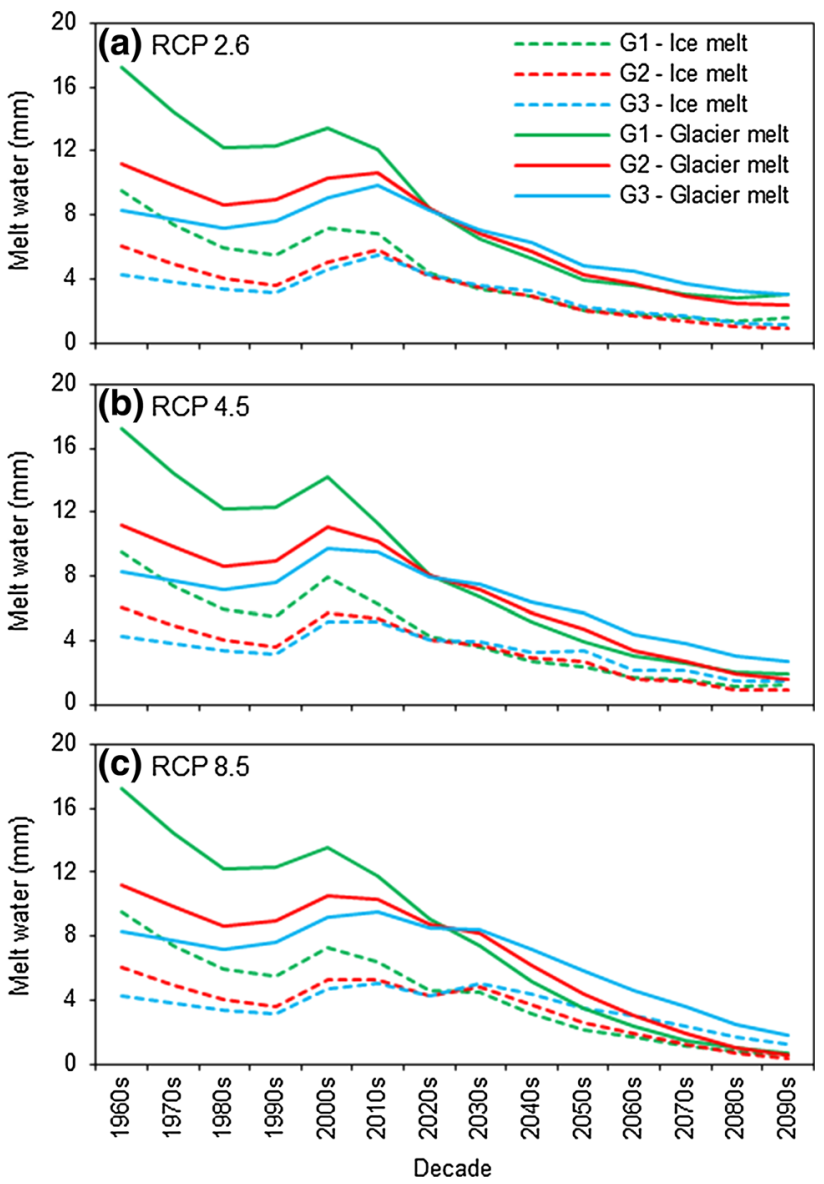

Fig. 7 Decadal ice melt and glacier melt of each grouped glacier size under RCP 2.6 (a) and RCP 4.5 (b) and RCP 8.5 (c) in the Urumqi River Basin

groups mainly occurs in historical period or even before. It was also found that the decreased rates of glacier melt are larger than that of ice melt at the two scales. This is mainly because the decreased rate of water yield on the ice surface (supraglacial snowmelt and rainfall-induced runoff) is larger than that of ice melt.

\section{Ice melt contribution to runoff}

Previous studies emphasized the importance of the buffering effect of glaciers, which release additional water during dry summers and compensate for rain shortfalls (Sorg et al. 2014). Ice melt causes discharge to increase in times of drought and therefore reduces runoff variability. The contributions of ice melt to river runoff at the two scales are shown in Table 6. The annual ice melt accounts for $12.5-50.0 \%$, with a mean of $28.5 \%$ for runoff in the UG1 sub-basin, while that in URB ranges from 2.0 to $12.8 \%$ with a mean of $6.1 \%$ in the baseline period. It should be noted that the contributions to runoff under the three RCPs do not make significant differences in ice melt. 
Table 6 Ice melt contribution to runoff in the Glacier No. 1 sub-basin and Urumqi River Basin

\begin{tabular}{|c|c|c|c|c|c|c|c|}
\hline \multirow[t]{2}{*}{ Scale } & \multirow{2}{*}{$\begin{array}{l}\text { Baseline } \\
(\%)\end{array}$} & \multicolumn{3}{|c|}{ Near future (2016-2045) (\%) } & \multicolumn{3}{|c|}{ Far future (2066-2095) (\%) } \\
\hline & & RCP 2.6 & $\mathrm{RCP} 4.5$ & RCP 8.5 & RCP 2.6 & $\mathrm{RCP} 4.5$ & RCP 8.5 \\
\hline Glacier No. 1 sub-basin & 28.5 & 35.2 & 33.7 & 37.8 & 13.7 & 13.2 & 9.2 \\
\hline Urumqi River Basin & 6.1 & 3.6 & 3.2 & 3.8 & 1.2 & 1.2 & 1.3 \\
\hline
\end{tabular}

Additionally, the mean contribution of ice melt is approximately $35 \%$ in near future; however, the contribution significantly decreased to approximately $10 \%$ in the far future in the UG1 sub-basin. At the basin scale, the proportions are approximately 3.5 and $1 \%$ for the near and far future, respectively.

It seems that the GCM-predicted ice melt declines after 2010 in URB and the role of glacier regulation would be weakened in the following years. Although the ice melt in URB is only a small proportion of runoff, it is a signal to the adjacent glacierized basins. Glaciers in the Tianshan Mountains have lost much of their volume in the past decades (Ding et al. 2006; Kutuzov and Shahgedanova 2009; Sorg et al. 2012). The shrinking glaciers have supplied ample quantities of water, with benefits for downstream water allocation in last decade. The most unfavorable condition is that the precipitation decreases with rising temperature, further intensifying ice melt in a short time. If no other sources can offset the water deficiency from the reduced ice melt, summer runoff will decrease.

\section{Uncertainty}

There are some uncertainties here that are mainly attributed to the modeling approach and GCM projections (Teng et al. 2012; Dickerson-Lange and Mitchell 2014; Honti et al. 2014), despite the good model performance during the historical period.

The model-oriented uncertainties are mainly due to the parameterization of the rare observed data for weather and runoff in glacierized areas. Fortunately, the long-term measured data from UG1 could be used to calibrate the melt factors for ice, the lapse rates and streamflow during the historical period, particularly the observed mass balance, which is included as an additional criterion to significantly reduce parameter uncertainty (Hagg et al. 2013). Nevertheless, more uncertainty is caused by the use of only one meteorological station, and how the melt factors and lapse rates will alter under climate change also introduces uncertainty into the melt water and runoff calculations (Stahl et al. 2008). It is noteworthy that large glaciers may split into small glaciers due to continuing retreat. This phenomenon is beyond the simulation function of the glacier-enhanced SWAT model. UG1 is a typical case of this, as it separated into two branches in 1993. The two branches have experienced the same pattern of climate change since the separation, but they have responded differently in glacier area and mass balance (Xu et al. 2011). During the simulation, UG1 was treated as an integral glacier. The glacier-enhanced model should be further improved in the future to reduce the impact of such separation for glacier dynamics because the issue is critical for estimating future changes in melt water.

Although GCMs simulate the physical processes of the climate system, the accuracy of the simulated hydrological processes from the GCM-projected temperature and precipitation remains low due to insufficient representation of the climate system, unknown greenhouse gas emission scenarios and initial conditions, and down-scaling methods (Woldemeskel et al. 2014). Different GCMs often result in different climate outputs from the same drivers (Liu et al. 2012). To reduce the uncertainty from individual GCM predictions, five GCM models were employed to drive this model. Furthermore, three RCPs were selected to cover a wide range of outcomes for each ensemble of GCMs to create a sufficient representation of the future climate system. Figure 8 shows the comparisons of simulated annual runoff during the baseline period and each GCM-predicted basin-wide runoff for two future periods under three RCPs. The results indicate greater runoff variability in all GCM predictions relative to the baseline period, especially in the far future. The trends in all GCM-predicted runoff are consistent in the two future periods. It was also found that greater variability occurs in CCSM4, CNRM-CM5 and MIROC5 predictions. In addition, more uncertainty may come from the delta change downscaling approach.

\section{Conclusions}

This paper analyzed the future potential changes in glaciohydrological processes in the headwaters of the Urumqi River. The GCM-predicted mean temperature and precipitation both increase under future scenarios. The following conclusions were obtained:

1. Glacier melt and runoff responses to climate change vary at the UG1 sub-basin scale and basin-wide scale. In the UG1 sub-basin, the ice melt and glacier melt are expected to significantly increase in the near future and sharply decline in the far future. The annual sub-basin runoff significantly increases in historical period and 

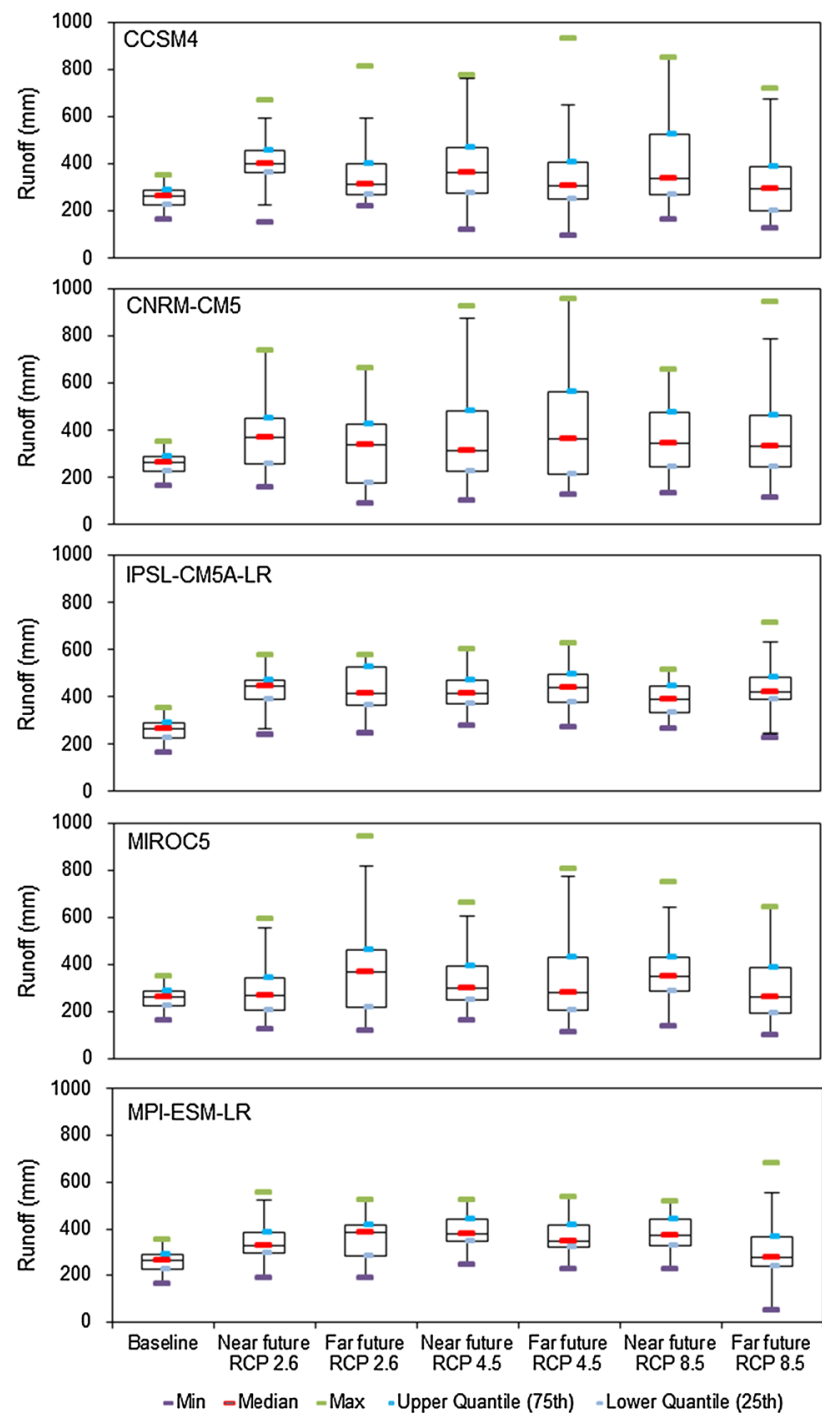

Fig. 8 Box plots for each GCM-predicted annual runoff in the Urumqi River Basin

would gradually decrease under all RCPs. In the URB, the ice melt and glacier melt would both rapidly decrease under all RCPs. Nevertheless, the runoff from URB influenced by precipitation is expected to remain stable under RCP 2.6 and RCP 4.5, with a slight decrease under RCP 8.5.

2. Small-sized glaciers exhibit a rapid shrinkage rate, both in the historical period and future scenarios, and all glaciers are predicted to disappear by the end of this century. Decadal ice melt and glacier melt from grouped glaciers exhibit clearly different responses to climate change. The melt water from the glacier group with sizes less than $0.5 \mathrm{~km}^{2}$ shows a rapid decrease, while the peak water is captured from the other groups.

3. The simulated river runoff is significantly influenced by GCM input weather data. Greater variability of runoff occurs in the all GCM predictions relative to the baseline period.

Acknowledgments This study was funded by National Natural Science Foundation of China (Grant No. 41130641), and Ministry of Science and Technology of China (Grant No. 2010DFA92720 and Grant No. 2012BAC19B07).

\section{References}

Abdo KS, Fiseha BM, Rientjes THM, Gieske ASM, Haile AT (2009) Assessment of climate change impacts on the hydrology of Gilgel Abay catchment in Lake Tana basin, Ethiopia. Hydrol Process 23(26):3661-3669

Arnold JG, Allen PM, Bernhardt G (1993) A comprehensive surfacegroundwater flow model. J Hydrol 142(1-4):47-69

Baraer M, Mark BG, McKenzie JM, Condom T, Bury J, Huh KI, Portocarrero C, Gomez J, Rathay S (2012) Glacier recession and water resources in Peru's Cordillera Blanca. J Glaciol 58(207):134-150

Bolch T (2007) Climate change and glacier retreat in northern Tien Shan (Kazakhstan/Kyrgyzstan) using remote sensing data. Glob Planet Change 56(1-2):1-12

Braun L, Hagg W (2009) Present and future impact of snow cover and glaciers on runoff from mountain regions - comparison between Alps and Tien Shan. Assess. In: Braun L, Hagg W, Severskiy I, Young G (eds) Assessment of snow, glacier and water resources in Asia. IHP/HWRP, Koblenz, pp 36-43

Chen J, Ohmura A (1990) Estimation of Alpine glacier water resources and their change since the 1870s. IAHS Publ 193:127-135

Chen J, Brissette FP, Leconte R (2011) Uncertainty of downscaling method in quantifying the impact of climate change on hydrology. J Hydrol 401(3-4):190-202

Chen RS, Qing WW, Liu SY, Han HD, He XB, Wang J, Liu GY (2012) The relationship between runoff and ground temperature in glacierized catchments in China. Environ Earth Sci 65(3):681-687

Collins DN (1998) Outburst and rainfall-induced peak runoff events in highly glacierized Alpine basins. Hydrol Process 12(15):2369-2381

Cui YH, Ye BS, Wang J, Liu YC (2013) Influence of degree-day factor variation on the mass balance of Glacier No. 1 at the Headwaters of Urumqi River, China. J Earth Sci China 24(6):1008-1022

Diaz-Nieto J, Wilby RL (2005) A comparison of statistical downscaling and climate change factor methods: impacts on low flows in the River Thames, United Kingdom. Clim Change 69(2-3):245-268

Dickerson-Lange SE, Mitchell R (2014) Modeling the effects of climate change projections on streamflow in the Nooksack River basin, Northwest Washington. Hydrol Process 28(20):5236-5250

Ding YJ, Liu SY, Li J, Shangguan DH (2006) The retreat of glaciers in response to recent climate warming in western China. Ann Glaciol 43:97-105

Feng F, Li ZQ, Jin S, Dong ZW, Wang FT (2012) Hydrochemical characteristics and solute dynamics of meltwater runoff of Urumqi Glacier No. 1, eastern Tianshan, northwest China. J Mt Sci-Engl 9(4):472-482

Gan R, Luo Y, Zuo Q, Sun L (2015) Effects of projected climate change on the glacier and runoff generation in the Naryn River Basin, Central Asia. J Hydrol 523:240-251 
Gao MJ, Han TD, Ye BS, Jiao KQ (2013) Characteristics of melt water discharge in the Glacier No. 1 basin, headwater of Urumqi River. J Hydrol 489:180-188

Hagg W, Hoelzle M, Wagner S, Mayr E, Klose Z (2013) Glacier and runoff changes in the Rukhk catchment, upper Amu-Darya basin until 2050. Glob Planet Change 110:62-73

Han TD, Ding YJ, Ye BS, Jiao KQ (2011) Characteristics of winter mass balance of Glacier No. 1 at the headwaters of the Urumqi River, Tianshan Mountains. Environ Earth Sci 63(4):695-700

Honti M, Scheidegger A, Stamm C (2014) The importance of hydrological uncertainty assessment methods in climate change impact studies. Hydrol Earth Syst Sc 18(8):3301-3317

Jansson P, Hock R, Schneider T (2003) The concept of glacier storage: a review. J Hydrol 282(1-4):116-129

Kriegel D, Mayer C, Hagg W, Vorogushyn S, Duethmann D, Gafurov A, Farinotti D (2013) Changes in glacierisation, climate and runoff in the second half of the 20th century in the Naryn basin, Central Asia. Glob Planet Change 110:51-61

Kutuzov S, Shahgedanova M (2009) Glacier retreat and climatic variability in the eastern Terskey-Alatoo, inner Tien Shan between the middle of the 19th century and beginning of the 21st century. Glob Planet Change 69(1-2):59-70

Li BL, Zhu AX, Zhang YC, Pei T, Qin CZ, Zhou CH (2006) Glacier change over the past four decades in the middle Chinese Tien Shan. J Glaciol 52(178):425-432

Li ZQ, Wang WB, Zhang MJ, Wang FT, Li HL (2010) Observed changes in streamflow at the headwaters of the Urumqi River, eastern Tianshan, central Asia. Hydrol Process 24(2):217-224

Liu SY, Ding YJ, Wang NL, Xie ZC (1998) Mass balance sensitivity to climate change of the Glacier No. 1 at the Urumqi River Head, Tianshan Mts. J Glaciol Geocryol 20(1):9-13 (in Chinese)

Liu CH, Shi YF, Wang ZT, Xie ZC (2000) Glacier resources and their distributive characteristics in China-a review on Chinese Glacier Inventory. J Glaciol Geocryol 22(2):106-112 (in Chinese)

Liu YL, Zhang JY, Wang GQ, Liu JF, He RM, Wang HJ, Liu CS, Jin JL (2012) Quantifying uncertainty in catchment-scale runoff modeling under climate change (case of the Huaihe River, China). Quat Int 282:130-136

Liu SY, Yao XJ, Guo WQ, Xu JL, Shangguan DH, Wei JF, Bao WJ, Wu LZ (2015) The contemporary glaciers in China based on the Second Chinese Glacier Inventory. Acta Geogr Sinica 70(1):3-16 (in Chinese)

Luo Y, Arnold J, Allen P, Chen X (2012) Baseflow simulation using SWAT model in an inland river basin in Tianshan Mountains, Northwest China. Hydrol Earth Syst Sc 16(4):1259-1267

Luo Y, Arnold J, Liu SY, Wang XY, Chen X (2013) Inclusion of glacier processes for distributed hydrological modeling at basin scale with application to a watershed in Tianshan Mountains, northwest China. J Hydrol 477:72-85

Lutz AF, Immerzeel WW, Shrestha AB, Bierkens MFP (2014) Consistent increase in High Asia's runoff due to increasing glacier melt and precipitation. Nat Clim Change 4(7):587-592

Ma C, Sun L, Liu S, Shao Ma, Luo Y (2015) Impact of climate change on the streamflow in the glacierized Chu River Basin, Central Asia. J Arid Land 7(4):501-513

Moriasi DN, Arnold JG, Van Liew MW, Bingner RL, Harmel RD, Veith TL (2007) Model evaluation guidelines for systematic quantification of accuracy in watershed simulations. Trans Asabe 50(3):885-900

Nash JE, Sutcliffe JV (1970) River flow forecasting through conceptual models part I-a discussion of principles. J Hydrol $10: 282-290$
Pouyaud B, Zapata M, Yerren J, Gomez J, Rosas G, Suarez W, Ribstein P (2005) On the future of the water resources from glacier melting in the Cordillera Blanca, Peru. Hydrol Sci J 50(6):999-1022

Singh R, van Werkhoven K, Wagener T (2014) Hydrological impacts of climate change in gauged and ungauged watersheds of the Olifants basin: a trading-space-for-time approach. Hydrol Sci J 59(1):29-55

Sorg A, Bolch T, Stoffel M, Solomina O, Beniston M (2012) Climate change impacts on glaciers and runoff in Tien Shan (Central Asia). Nat Clim Change 2(10):725-731

Sorg A, Mosello B, Shalpykova G, Allan A, Clarvis MH, Stoffel M (2014) Coping with changing water resources: the case of the Syr Darya river basin in Central Asia. Environ Sci Policy 43:68-77

Stahl K, Moore RD, Shea JM, Hutchinson D, Cannon AJ (2008) Coupled modelling of glacier and streamflow response to future climate scenarios. Water Resour Res 44(2):W02422

Suarez W, Chevallier P, Pouyaud B, Lopez P (2008) Modelling the water balance in the glacierized Paron Lake basin (White Cordillera, Peru). Hydrol Sci J 53(1):266-277

Taylor KE, Stouffer RJ, Meehl GA (2012) An overview of Cmip5 and the experiment design. Bull Am Meteorol Soc 93(4):485-498

Teng J, Vaze J, Chiew FHS, Wang B, Perraud JM (2012) Estimating the relative uncertainties sourced from GCMs and hydrological models in modeling climate change impact on runoff. J Hydrometeorol 13(1):122-139

Unger-Shayesteh K, Vorogushyn S, Farinotti D, Gafurov A, Duethmann D, Mandychev A, Merz B (2013) What do we know about past changes in the water cycle of Central Asian headwaters? A review. Glob Planet Change 110:4-25

van Vuuren DP, Edmonds J, Kainuma M, Riahi K, Thomson A, Hibbard K, Hurtt GC, Kram T, Krey V, Lamarque JF, Masui T, Meinshausen M, Nakicenovic N, Smith SJ, Rose SK (2011) The representative concentration pathways: an overview. Clim Change 109(1-2):5-31

Wang L, Wang FT, Li ZQ, Wang WB, Li HL, Wang PY (2015) Glacier changes in the Sikeshu River basin, Tienshan Mountains. Quat Int 358:153-159

Winchell M, Srinivasan R, Di Luzio M, Arnold J (2007) Arc-SWAT interface for SWAT2005-user's guide. USDA Agricultural Research Service and Texas A\&M Blackland Research Center, Temple

Woldemeskel FM, Sharma A, Sivakumar B, Mehrotra R (2014) A framework to quantify GCM uncertainties for use in impact assessment studies. J Hydrol 519:1453-1465

Wu J, Luo Y, Li J, Li CX, Yuan L, Yang LM (2014) Evaluation of CMIP5 modes's simulation ability in the northwest arid areas of China. Arid Land Geogr 37(3):499-508 (in Chinese)

Xu XK, Pan BL, Hu E, Li YJ, Liang YH (2011) Responses of two branches of Glacier No. 1 to climate change from 1993 to 2005, Tianshan, China. Quat Int 236:143-150

Zhang WC, Chen J, Ogawa K, Yamaguchi Y (2005) An approach to estimating evapotranspiration in the Urumqi River basin, Tianshan, China, by means of remote sensing and a geographical information system technique. Hydrol Process 19(9):1839-1854

Zhang GF, Li ZQ, Wang WB, Wang WD (2014) Rapid decrease of observed mass balance in the Urumqi Glacier No. 1, Tianshan Mountains, central Asia. Quat Int 349:135-141

Zhao ZP, Tian L, Fischer E, Li ZQ, Jiao KQ (2008) Study of chemical composition of precipitation at an alpine site and a rural site in the Urumqi River Valley, Eastern Tien Shan, China. Atmos Environ 42(39):8934-8942 